ORIGINAL ARTICLE

\section{Marburg Hemorrhagic Fever Associated with Multiple Genetic Lineages of Virus}

\author{
Daniel G. Bausch, M.D., M.P.H., Stuart T. Nichol, Ph.D., \\ Jean Jacques Muyembe-Tamfum, M.D., Ph.D., Matthias Borchert, M.D., \\ Pierre E. Rollin, M.D., Hilde Sleurs, M.D., Patricia Campbell, M.D., \\ Florimund K. Tshioko, M.D., Catherine Roth, M.B.B.Ch., \\ Robert Colebunders, M.D., Ph.D., Patricia Pirard, M.D., \\ Simon Mardel, M.B., B.S., F.R.C.S., Loku A. Olinda, M.D., Hervé Zeller, Ph.D., \\ Antoine Tshomba, M.D., Amayo Kulidri, M.D., Modeste L. Libande, R.N., \\ Sabue Mulangu, M.D., Pierre Formenty, D.V.M., Thomas Grein, M.D., \\ Herwig Leirs, Ph.D., Leo Braack, Ph.D., Tom Ksiazek, D.V.M., Ph.D., \\ Sherif Zaki, M.D., Ph.D., Michael D. Bowen, Ph.D., Sheilagh B. Smit, B.Sc., \\ Patricia A. Leman, B.Sc., Felicity J. Burt, Ph.D., Alan Kemp, M.Sc., \\ and Robert Swanepoel, B.V.Sc., Ph.D., for the International Scientific \\ and Technical Committee for Marburg Hemorrhagic Fever Control \\ in the Democratic Republic of the Congo**
}

A BSTRACT

BACKGROUND

An outbreak of Marburg hemorrhagic fever was first observed in a gold-mining village in northeastern Democratic Republic of the Congo in October 1998.

\section{METHODS}

We investigated the outbreak of Marburg hemorrhagic fever most intensively in May and October 1999. Sporadic cases and short chains of human-to-human transmission continued to occur until September 2000. Suspected cases were identified on the basis of a case definition; cases were confirmed by the detection of virus antigen and nucleic acid in blood, cell culture, antibody responses, and immunohistochemical analysis.

\section{RESULTS}

A total of 154 cases (48 laboratory-confirmed and 106 suspected) were identified (case fatality rate, 83 percent); 52 percent of cases were in young male miners. Only 27 percent of these men reported having had contact with other affected persons, whereas 67 percent of patients who were not miners reported such contact $(\mathrm{P}<0.001)$. Most of the affected miners (94 percent) worked in an underground mine. Cessation of the outbreak coincided with flooding of the mine. Epidemiologic evidence of multiple introductions of infection into the population was substantiated by the detection of at least nine genetically distinct lineages of virus in circulation during the outbreak.

\section{CONCLUSIONS}

Marburg hemorrhagic fever can have a very high case fatality rate. Since multiple genetic variants of virus were identified, ongoing introduction of virus into the population helped perpetuate this outbreak. The findings imply that reservoir hosts of Marburg virus inhabit caves, mines, or similar habitats.
From the Centers for Disease Control and Prevention, Atlanta (D.G.B., S.T.N., P.E.R., T.K., S.Z., M.D.B.); Tulane School of Public Health and Tropical Medicine, New Orleans (D.G.B.); Ministry of Health (J.J.M.-T., S. Mulangu) and Institut National de Recherche Biomédicale (J.J.M.-T.), Kinshasa, Democratic Republic of the Congo; Institute of Tropical Medicine, Antwerp, Belgium (M.B., R.C.); Médecins sans Frontières, Belgium (M.B., H.S., R.C., P.P.) and the Netherlands (P.C.); World Health Organization, Kinshasa/Kisangani, Democratic Republic of the Congo (F.K.T.) and Geneva (C.R., S. Mardel, P.F., T.G.); the Ministry of Health, Kisangani, Democratic Republic of the Congo (L.A.O.); Institut Pasteur, Paris (H.Z.); Offices de Mines d'Or de Kilo Moto Hospital (A.T.) and Ministry of Health (A. Kulidri, M.L.L.), Watsa, Democratic Republic of the Congo; Danish Pest Infestation Laboratory, Lyngby, Denmark (H.L.); South African National Parks Board, Pretoria (L.B.); and National Institute for Communicable Diseases, Johannesburg (S.B.S., P.A.L., F.J.B., A. Kemp, R.S.). Address reprint requests to Dr. Swanepoel at the National Institute for Communicable Diseases, Private Bag X4, Sandringham 2131, South Africa, or at bobs@nicd.ac.za.

*Additional participants in this study are listed in the Appendix.

N Engl J Med 2006;355:909-19.

Copyright $\odot 2006$ Massachusetts Medical Society. 
T HE FILOVIRUSES MARBURG AND EBOLA cause severe hemorrhagic fevers with high case fatality rates. Marburg virus (Lake Victoria subtype) of the family Filoviridae was first isolated and Marburg hemorrhagic fever first described in 1967 during outbreaks in Germany and Yugoslavia. These outbreaks were linked to infected monkeys imported from Uganda. ${ }^{1-4}$ Three minor outbreaks involving one to three cases were subsequently reported in Africa between 1975 and 1987.5-9 Transmission of the virus between humans is poorly understood, and the natural reservoir remains unknown.

In October 1998, the chief medical officer for Watsa Zone in northeastern Democratic Republic of the Congo reported the occurrence of a fatal hemorrhagic syndrome in young men working in gold mines in the village of Durba. Owing to continued military activity of the civil war of 1997, it was only after the doctor himself died of the disease on April 23, 1999, that an investigative team was able to enter the area. On May 6, a diagnosis of Marburg hemorrhagic fever was confirmed from samples sent to the National Institute for Communicable Diseases (NICD) in Johannesburg, South Africa. ${ }^{10,11}$

At the request of Congo's Ministry of Health, an international team of experts, coordinated by the World Health Organization, arrived in Durba on May 8, 1999, to assist local officials in the investigation and control efforts. ${ }^{12,13}$ The team found that the outbreak had subsided, and they departed after three weeks. However, continued reports of sporadic cases prompted a follow-up mission in October 1999. This report describes the laboratory diagnosis, virus phylogeny, epidemiology, and clinical presentation of Marburg hemorrhagic fever revealed by the two investigations, as well as by sustained surveillance by local officials with intermittent outside assistance.

\section{METHODS}

\section{OUTBREAK AREA}

The outbreak of Marburg hemorrhagic fever centered on the mining village of Durba, which has an estimated population of 25,000 , and the nearby district capital Watsa (population, 60,000), approximately $150 \mathrm{~km}$ from the borders of Uganda and Sudan. At the time of the outbreak, the area was held by Ugandan soldiers and Congolese rebels in opposition to the government of Congo. Gold mining is the major economic activity in the re-
Figure 1 (facing page). Cases of Marburg Hemorrhagic Fever in the Area of Durba and Watsa, Democratic Republic of the Congo, October 1998 to October 2000, According to Whether the Case Was Suspected or Confirmed (Panel A) and the Patients' Occupations (Panel B). The date of onset was not precisely known for 27 patients and was assumed to be seven days before either death or hospitalization. In Panel B, patients listed as family or community members included 31 housewives, 15 children, 6 traders, 5 farmers, and 6 persons in other assorted professions.

gion, supplemented by subsistence farming and hunting. Organized commercial mining ceased when the civil war reached Durba in 1997 and was replaced by illegal, albeit open, mining involving mainly young, untrained men.

The government-sponsored Reference Health Center in Durba was a rudimentary facility staffed by a few nurses, and most seriously ill people sought care $15 \mathrm{~km}$ away at the two hospitals in Watsa: Watsa General Reference Hospital, a 56-bed government regional reference center, and a 70-bed private hospital affiliated with the mining company, the Offices de Mines d'Or de Kilo Moto (OKIMO). There were 16 additional small health centers in the area of Durba and Watsa, but medical supplies were severely limited at all facilities. Toward the end of the outbreak, the Reference Health Center in Durba was refurbished and used as the main treatment center for Marburg hemorrhagic fever.

\section{CASE AND CONTACT DEFINITIONS}

A confirmed diagnosis of the disease required the following: acute illness for up to three weeks in the absence of associated trauma, another focal disease process, or a response to antibiotics or antimalarial agents; at least three of the following signs and symptoms: fever, generalized body pains, nausea and vomiting, headache, anorexia, malaise, abdominal pain, diarrhea, dyspnea, dysphagia, hiccups, conjunctivitis, rash or petechiae, and abnormal bleeding from the nose, mouth, gastrointestinal tract, or genitourinary tract; and a positive laboratory test for Marburg virus infection. Patients were suspected of having the disease if they had the characteristic clinical syndrome, even if they had no specimens available for laboratory confirmation. A contact was defined as someone who had had physical contact with a patient with confirmed or suspected Marburg virus infection during acute illness or after death, or with fomites. 


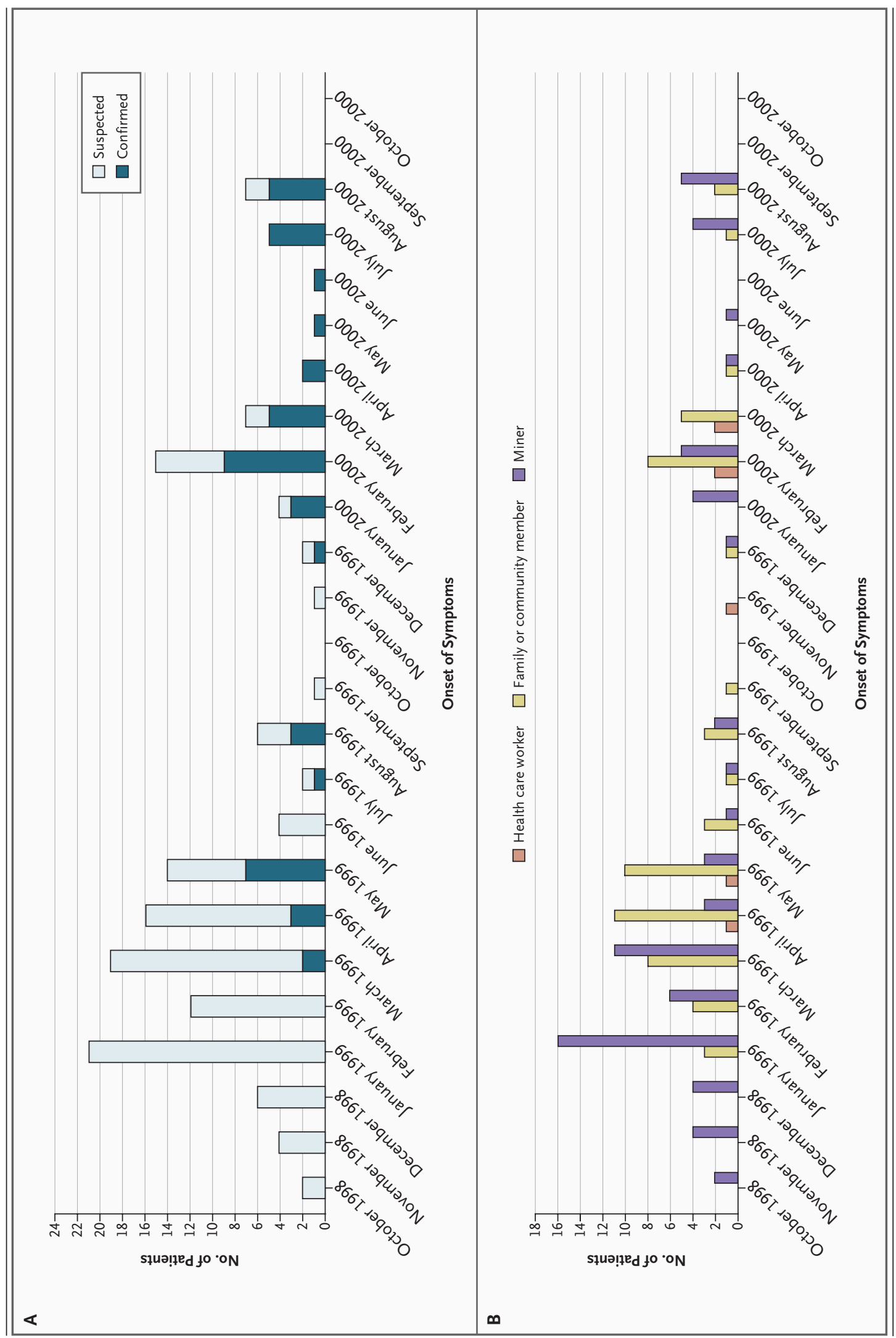


Table 1. Laboratory Confirmation of Marburg Hemorrhagic Fever in 48 Patients in the Democratic Republic of the Congo, 1999-2000.

Test

Performed 1-15 days after onset

Antigen-detection ELISA

L gene RT-PCR

Nested RT-PCR of VP35

Virus isolation

IgM-antibody ELISA

IgG-antibody ELISA

Immunohistochemical analysis

Performed post mortem 3-8 days after onset

Immunohistochemical analysis

Performed 31-1376 days after onset

IgM-antibody ELISA

IgG-antibody ELISA

* The results of immunohistochemical analysis were negative for 26 other patients suspected of having Marburg hemorrhagic fever for whom data were discarded as unconfirmed.

$\uparrow$ One patient consented to being tested 1376 days after the onset of illness.

Data could not be obtained for several other patients.

\section{SURVEILLANCE AND CARE OF PATIENTS}

We searched for patients by reviewing available records of patients and death registers at all health facilities and pharmacies in the area of Durba and Watsa dating back to October 1998. If clinical data suggested a diagnosis of viral hemorrhagic fever, the patient was seen and the hospital chart retrieved, if possible. Investigators also attempted to interview patients with suspected cases and survivors or their family members and followed up on rumors. Contacts of patients with confirmed or suspected disease were followed daily for signs of illness for the maximum incubation period (21 days) and placed in an isolation ward if they became ill. ${ }^{14}$ To gain insight into possible previous transmission of Marburg virus in the area, we reviewed hospital records as far back as possible and conducted interviews with local medical personnel, community leaders, and survivors of possible previous outbreaks.

\section{LABORATORY ANALYSIS}

Whole-blood samples drawn from patients with suspected cases were shipped on dry ice to the NICD or, on occasion, to the Centers for Disease Control and Prevention (CDC), where they were tested by enzyme-linked immunosorbent assay (ELISA) for Marburg virus antigen and Marburg virus-specific IgM and IgG antibodies and by reverse-transcriptase-polymerase-chain-reaction (RT-PCR) assay for Marburg virus nucleic acid and were cultured in Vero 76 or Vero E6 cells in an effort to isolate the virus, with the use of modifications of techniques previously published for Ebola hemorrhagic fever. ${ }^{15-17}$ Punch-biopsy specimens of skin were obtained from deceased persons, fixed in 10 percent formalin, and sent to the CDC for immunohistochemical analysis, as described previously. ${ }^{18}$ Primers used in RT-PCR assays included published sequences targeting a filovirus-specific segment of the polymerase (L) gene ${ }^{17}$ and nested primers targeting the Marburg virus VP35 gene, designed at the CDC. (The RT-PCR analysis, nucleotide sequencing of amplicons, and sequence data analysis are described in the Supplementary Appendix, available with the full text of this article at www.nejm.org.)

A patient was considered to have Marburg hemorrhagic fever if any of the following laboratory tests was positive: ELISA antigen detection, RT-PCR assay, virus culture, ELISA IgM antibody, ELISA IgG antibody in a patient with a clinical or epidemiologic history compatible with Marburg hemorrhagic fever, or immunohistochemical analysis.

\section{ENVIRONMENTAL ASSESSMENT}

Investigators visited all mining sites in Durba with members of the mining company. During the visit, they recorded the geographic location, the type of mining (surface or underground), the working conditions at the mine, and the number of workers at each site.

\section{STATISTICAL ANALYSIS}

Data that were collected in the field were recorded on case-report and contact-tracing forms, entered into an Epi Info 6.0 database (CDC), and imported into SPSS version 10.0 (SPSS) for further analysis, with use of the chi-square test, Fisher's exact test, and Student's t-test, as appropriate. Twosided $P$ values were calculated with a $P$ value of less than 0.05 used to indicate statistical significance.

\section{RESULTS}

\section{TIMELINE AND DEMOGRAPHIC CHARACTERISTICS} OF PATIENTS

From October 1998, when the first case was identified, through September 2000, when the last case was identified, there were 154 cases $(48$ confirmed 
and 106 suspected) (Fig. 1A). Of the 48 patients with confirmed cases, 34 had positive test results for ELISA antigen, RT-PCR, or virus isolation; 6 who were tested late in the course of the disease were antibody-positive only; and 8 received a diagnosis on the basis of positive results on immunohistochemical analysis of postmortem skin samples (Table 1).

The RT-PCR assay was positive for the $\mathrm{L}$ gene in blood samples from 31 of 34 patients with virologically confirmed cases (but positive on all cellculture isolates), whereas the nested PCR assay for Marburg virus protein 35 (VP35) protein was positive in samples from all 33 patients tested. (One sample had insufficient material to be tested for VP35 protein.) Three blood samples that were positive on PCR had no virus isolated in culture, but one had been heat-inactivated before culture and another had heavy bacterial contamination.

Because of the initial delay in gaining access to the area of Durba and Watsa, 52 percent of the cases occurred before the arrival of the first international team and were identified retrospectively. Most cases were in young adult male miners residing in Durba, followed by housewives and infants (Table 2). Of the 145 patients for whom demographic data were available, 18 (12 percent) were under the age of 15 years. Marburg hemorrhagic fever was noted in members of at least eight ethnic or linguistic groups. Although cases were reported from Watsa and various surrounding villages, further investigation invariably revealed a link to Durba. Many patients who listed a place of residence other than Durba were found to have been living and working in Durba at the time of their illness.

\section{SOURCE OF PRIMARY INFECTION AND TRANSMISSION}

A seasonal pattern was noted during the two years of observation, with transmission typically beginning in October or November and peaking in January or February (Fig. 1A). On each occasion, the upsurge in cases was primarily among miners and was followed by spread to their families and other members of the community and punctuated by occasional nosocomial infections (Fig. 1B).

Multiple short, apparently independent chains of transmission were noted, with seven being the largest number of cases noted in any single chain. Incidences of secondary spread from at least 20 patients, tertiary spread from at least 3 patients,

\begin{tabular}{lc}
$\begin{array}{l}\text { Table 2. Demographic Characteristics of Patients } \\
\text { with Marburg Hemorrhagic Fever in Durba, Democratic } \\
\text { Republic of the Congo, 1998-2000.* }\end{array}$ \\
\hline $\begin{array}{l}\text { Characteristic } \\
\text { Male sex - no./total no. (\%) }\end{array}$ \\
Age & $104 / 153(68)$ \\
Mean -yr & 28 \\
Range & 7 days to 72 yr \\
Occupation - no./total no. (\%) & \\
Miner & $75 / 145(52)$ \\
Housewife & $31 / 145(21)$ \\
Infant & $15 / 145(10)$ \\
Health care worker & $7 / 145(5)$ \\
Trader & $6 / 145(4)$ \\
Farmer & $5 / 145(3)$ \\
Other $†$ & $6 / 145(4)$ \\
Village of residence - no./total no. (\%) & \\
Durba & $121 / 151(80)$ \\
Watsa & $24 / 151(16)$ \\
Other & $6 / 151(4)$ \\
\end{tabular}

* Data were not available for all patients in each category. $\uparrow$ Patients in this category included two teachers, two students, an electrician in the Goroumbwa mine workshop, and a retired nurse who had been out of the profession for a long time. No occupation was recorded for nine patients, but eight of the nine were young men, mostly from Durba, who were probably miners.

and quaternary spread from at least 2 patients were documented, most often related to the exposure of family members caring for a sick miner. The conclusion that independent chains of infection began in miners is supported by the finding that only 20 of 75 miners ( 27 percent) reported having had previous contact with someone with Marburg hemorrhagic fever. This number contrasts with 20 of 31 housewives (65 percent), 11 of 15 infants (73 percent), 6 of 7 health care workers (86 percent), and 10 of 17 members of other professions (59 percent) for whom such contact was reported $(\mathrm{P}<0.001$ for the comparison between miners and all other groups collectively). Furthermore, 33 of 49 female patients ( 67 percent), of whom 29 were housewives, reported having had previous contact with someone with Marburg hemorrhagic fever, as compared with 33 of 104 men (32 percent) $(\mathrm{P}<0.001)$. This finding suggests that in contrast to men, women frequently contracted the virus through secondary transmission in their tradi- 
tional roles as caretakers for sick persons in the home. The association between mining and apparent primary infection remained significant after controlling for the stage of the epidemic, the village of residence, and type of case (confirmed vs. suspected).

Unlike most filovirus outbreaks, nosocomial infection did not play an important role in virus transmission in the area of Durba and Watsa. Five separate incidents at two health centers resulted in six infections among health care workers (three nurses, one doctor, one midwife, and one nursemidwife). ${ }^{19} \mathrm{~A}$ case of the disease was also noted in a traditional healer, but the circumstances of infection were not available.

The nucleotide sequences were determined for amplified gene fragments of Marburg virus (GenBank accession numbers DQ466108 through DQ466195 and DQ447652). Maximum likelihood analysis of sequence differences detected among Marburg virus VP35 gene fragments from various cases revealed that at least nine genetic lineages of Marburg virus were in circulation during the Durba outbreak. These lineages have been designated 1 through 9 for convenience, with the numbers bearing no taxonomic significance (Fig. 2). Phylogenetic analysis of sequence data on $\mathrm{L}$ gene fragments yielded the same nine lineages (results not shown). The genetic stability of the lineages and reproducibility of the findings are borne out by the facts that identical results were obtained for sequential samples from three patients and for sequences determined directly from clinical specimens or on cultured virus isolates from all patients. Moreover, identical results were obtained for split samples from four patients that were sequenced independently at the two participating laboratories (CDC and NICD). Identical sequences were also found within but not across clusters of epidemiologically linked patients (Fig. 2), although there was a tendency for the same lineages of virus to reappear at irregular intervals during the two-year outbreak.

\section{CLINICAL PRESENTATION AND CASE FATALITY RATE}

Of the 150 patients with Marburg hemorrhagic fever for whom information was available, 97 sought medical care (65 percent), and these patients presented for treatment a median of 4.5 days (range, 0 to 24) after the onset of symptoms. Clinical information was available for 129 patients: through examination or review of medical records for 95 patients and retrospective interviews with the patient or relatives for 34 patients (Table 3). At least three pregnant women with Marburg hemorrhagic fever were reported, all of whom died; one had a miscarriage, and one delivered an infant who died seven hours after birth.

The case fatality rate was 83 percent (125 of 150 patients) and did not vary significantly according to age, sex, profession, medical treatment, place of medical care (hospital vs. health center), time from the onset of symptoms until admission, phase of the outbreak, or status as a laboratory-confirmed case (vs. a suspected case) or primary transmission (vs. secondary transmission). Among patients who died, the deaths occurred a median of 7.0 days (range, 0 to 70) after the onset of symptoms. Mortality was significantly increased in persons with conjunctival injection and hiccups and decreased in those with chest pain (Table 3). Difficulty in breathing and most bleeding signs were more frequent in patients who died than in survivors, although differences were not significant. Many of the associations with fatal disease have been previously noted as indicators of end-stage filovirus infection. ${ }^{20}$

\section{HISTORICAL REVIEW}

Interviews and reviews of hospital records revealed that a disease called "syndrome hémorragique de Durba," which was always associated with mining, was common knowledge among villagers and health care workers in the area of Durba and Watsa. A doctor at OKIMO reportedly first recognized the disease in a male miner in 1987, and it became common practice in the 1990s for such patients to be admitted to Watsa General Reference Hospital. Many health care workers recalled past clusters of the disease among miners, often with nosocomial transmission, and the disease was usually fatal. Outbreaks involving at least 50 patients in total reportedly occurred in 1987, 1990, and 1992. An outbreak in 1994 involved an estimated 20 patients, including 1 doctor and 2 nurses, at least 8 of whom died. An outbreak in 1996 involved two nurses, both of whom died, and an outbreak in 1997 involved five patients, including one nurse, all of whom died. A former nurse who was found to be positive for Marburg IgG antibodies reported that he, a doctor, and a fellow nurse had contracted illnesses similar to Marburg hemorrhagic fever after performing obstetric surgery on a patient with probable disease in 1994. The doctor and one 


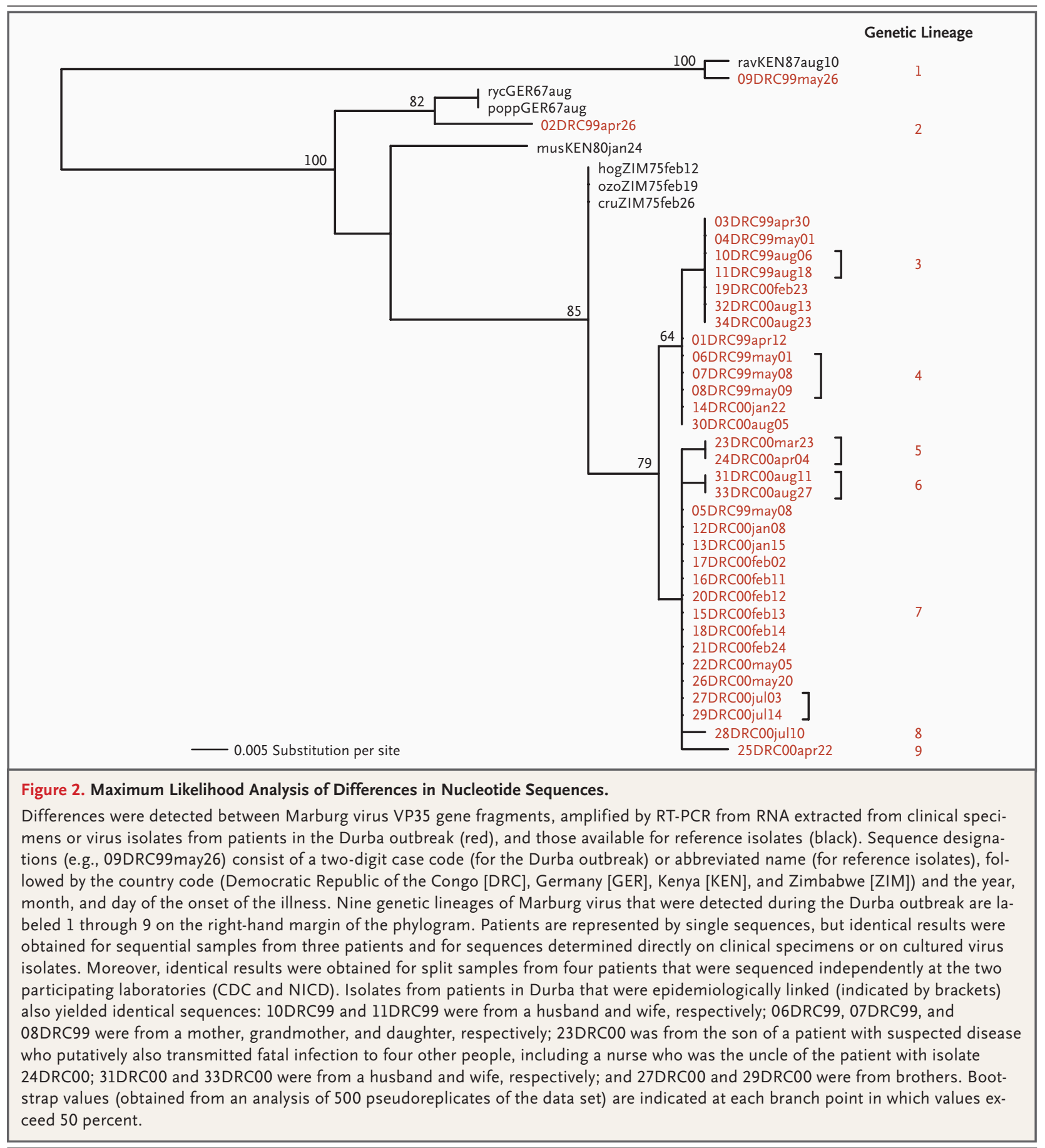

nurse died of the disease. Hospital records dating the arrival of his successor, the doctor who died back to 1991 (the earliest available) corroborated while investigating the outbreak reported here the existence of sporadic cases of the disease, par- (Fig. 3). Admissions again declined during the civil ticularly at Watsa General Reference Hospital, in- war of 1997. No specific trends were apparent with cluding a larger outbreak in 1994 (Fig. 3). After a regard to age or sex, and no further information doctor died in 1994, admissions to the hospital was available on professional or other exposures remained at a low level for more than a year until for these historical cases. 
Table 3. Recorded Signs and Symptoms for 129 Patients with Marburg Hemorrhagic Fever in the Area of Durba and Watsa, Democratic Republic of the Congo, 1998-2000.*

\begin{tabular}{|c|c|c|c|}
\hline \multirow[t]{2}{*}{ Sign or Symptom } & $\begin{array}{l}\text { All Patients } \\
(\mathrm{N}=129)\end{array}$ & $\begin{array}{l}\text { Survivors } \\
(\mathrm{N}=22)\end{array}$ & $\begin{array}{l}\text { Patients Who } \\
\text { Died ( } \mathrm{N}=107)\end{array}$ \\
\hline & \multicolumn{3}{|c|}{ number (percent) } \\
\hline \multicolumn{4}{|l|}{ Non-hemorrhagic } \\
\hline Fever & $120(93)$ & $22(100)$ & $98(92)$ \\
\hline Malaise or fatigue & $108(84)$ & $19(86)$ & $89(83)$ \\
\hline Headache & $101(78)$ & $16(73)$ & $85(79)$ \\
\hline Nausea or vomiting & $98(76)$ & $17(77)$ & $81(76)$ \\
\hline Anorexia & $94(73)$ & $17(77)$ & $77(72)$ \\
\hline Abdominal pain & $74(57)$ & $13(59)$ & $61(57)$ \\
\hline Diarrhea & $73(57)$ & $13(59)$ & $60(56)$ \\
\hline Myalgia or arthralgia & $71(55)$ & $12(55)$ & $59(55)$ \\
\hline Difficulty breathing & $70(54)$ & $8(36)$ & $62(58)$ \\
\hline Difficulty swallowing or sore throat & $53(41)$ & $7(32)$ & $46(43)$ \\
\hline Hiccups & $51(40)$ & $4(18)$ & $47(44) \dagger$ \\
\hline Conjunctival injection or red eyes & $48(37)$ & $3(14)$ & $45(42) ‡$ \\
\hline Lumbar pain & $10(8)$ & $1(5)$ & $9(8)$ \\
\hline Chest pain & $8(6)$ & $4(18)$ & $4(4) \dagger$ \\
\hline Cough & $7(5)$ & $2(9)$ & $5(5)$ \\
\hline Agitation & $2(2)$ & 0 & $2(2)$ \\
\hline \multicolumn{4}{|l|}{ Hemorrhagic } \\
\hline Hematemesis & $96(74)$ & $15(68)$ & $81(76)$ \\
\hline Melena & $71(55)$ & $9(41)$ & $62(58)$ \\
\hline Gingival bleeding & $44(34)$ & $5(23)$ & $39(36)$ \\
\hline Epistaxis & $40(31)$ & $4(18)$ & $36(34)$ \\
\hline Petechiae & $9(7)$ & $2(9)$ & $7(7)$ \\
\hline Bleeding from injection sites & $8(6)$ & 0 & $8(7)$ \\
\hline Hemoptysis & $6(5)$ & $2(9)$ & $4(4)$ \\
\hline Hematoma & $3(2)$ & 0 & $3(3)$ \\
\hline Bleeding from any site & $89(69)$ & $13(59)$ & $76(71)$ \\
\hline
\end{tabular}

* Of the 129 patients, 40 had laboratory-confirmed disease and 89 had suspected disease.

$\dagger \mathrm{P}=0.03$ for the comparison between survivors and those who died.

$t \mathrm{P}=0.01$ for the comparison between survivors and those who died.

\section{ENVIRONMENTAL ASSESSMENT}

Mining was conducted at seven sites in Durba during the outbreak, and in addition, alluvial gold was recovered by divers at a few sites along the Kibali River. Five of the mining sites consisted of surface diggings or small pits, and these were essentially devoid of vertebrate fauna. A sixth site, the Durba mine, consisted of short tunnels into a hillside where the ore appeared to be depleted, and dig- ging occurred mainly on the hillside above the tunnels. Most mining took place at the seventh site, the Goroumbwa mine, where there was a large quarry that had been exploited historically, plus two vertical shafts from which horizontal tunnels extended at various levels to the ore body, at a maximum depth of approximately $400 \mathrm{~m}$. Miners gained unauthorized access to the underground workings through an opening at the base of the quarry and reportedly remained underground for up to a week at a time. Owing to problems with drainage pumps, flooding began in 1995, and the Goroumbwa mine was completely inundated by September 2000 . The illegal and spontaneous nature of the mining activities precluded accurate estimates of the number of miners who worked at each site.

Of the 53 miners with Marburg hemorrhagic fever for whom information was obtained, 50 (94 percent) worked in Goroumbwa, which suggested that exposure to the fauna or flora of the mine was a risk factor. Animals found in the Goroumbwa mine included bats, rodents, shrews, frogs, snakes, cockroaches, crickets, spiders, wasps, and moth flies, although there was no history of direct exposure to animals or insect bites in any patient with Marburg hemorrhagic fever. However, the environment was heavily soiled with human and bat excrement, and the miners typically worked with rudimentary hand tools and without protective gear. The only other vertebrates that were detected were small populations of bats in the short tunnels of the Durba mine, where two patients with the disease were known to have worked. However, the implication that the Goroumbwa mine was the principal site of infection is supported by the lack of detection of a single case of the disease among 104 patients from the area of Durba and Watsa who were suspected of having the disease and were tested in continued surveillance from the time that the mine closed in September 2000 through December 2005.

\section{DISCUSSION}

Despite the fact that Marburg virus is thought to be maintained in nature exclusively in Africa, the 1998-2000 epidemic of Marburg hemorrhagic fever in the area of Durba and Watsa was the first outbreak recorded in a community setting in which the presumed primary cases occurred in indigenous Africans. ${ }^{1-7}$ Although the lack of infrastructure in this remote, impoverished, and war-torn 


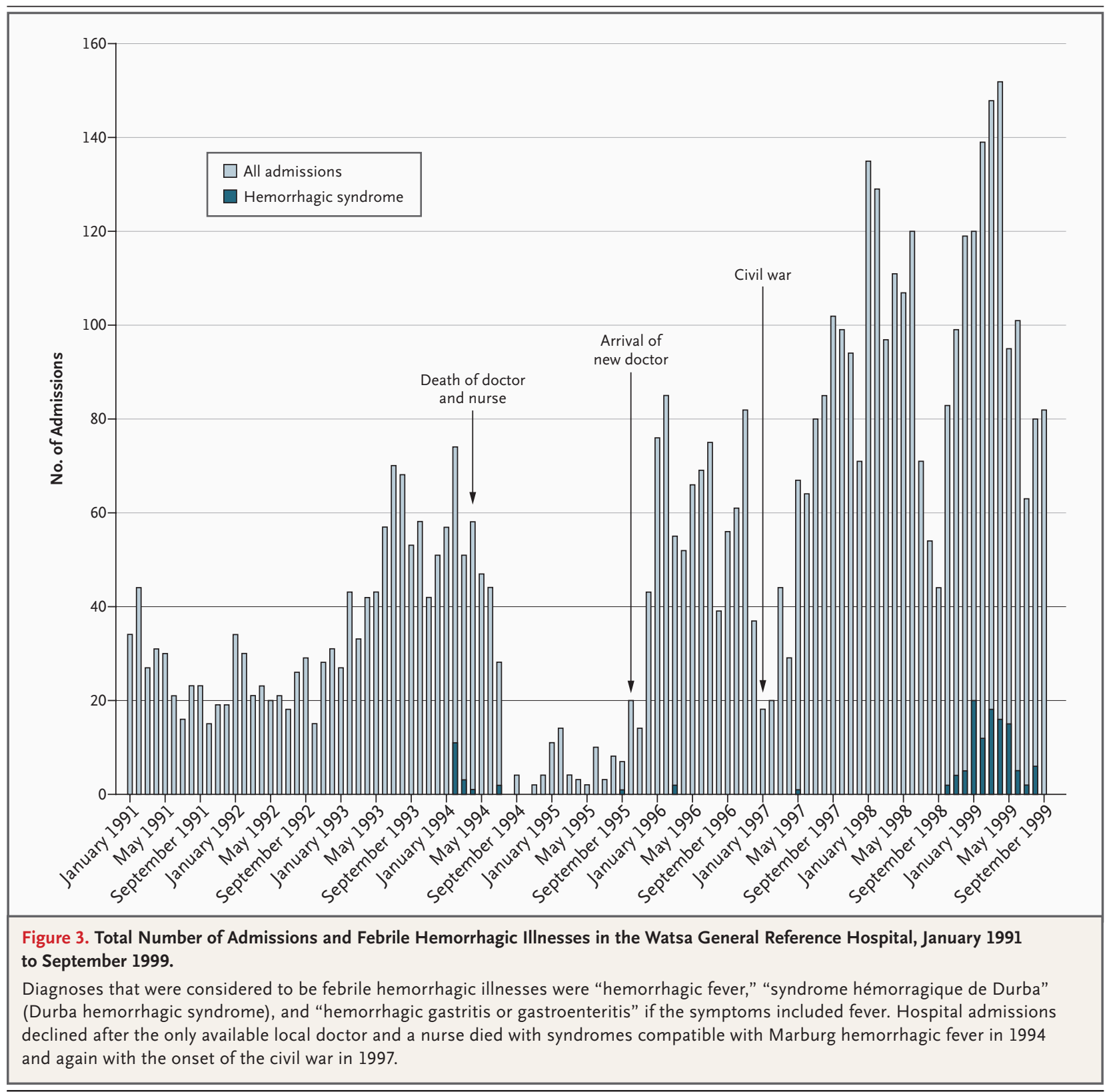

location hampered the collection of data, several new features of the disease were revealed by the investigation.

Bleeding was more frequent and rash much less common in the area of Durba and Watsa than in previous outbreaks of the disease. , $^{2,3,5-8,21,22} \mathrm{Al}-$ though mild nonhemorrhagic cases have been described that might escape detection, data regarding seroprevalence do not support the occurrence of frequent subclinical infections in the area of Durba and Watsa or elsewhere. ${ }^{23-25}$ Bleeding appears to be more common in Marburg hemor- rhagic fever than in Ebola hemorrhagic fever, in which it was noted in a minority of cases in some outbreaks. ${ }^{26,27}$ Rash may have simply been more difficult to detect in darker-skinned Africans in the area of Durba and Watsa than in white patients who were involved in past outbreaks of Marburg hemorrhagic fever. Similar racial disparities have been noted between expatriate missionaries and Africans with Ebola hemorrhagic fever. ${ }^{20,28,29} \mathrm{Al}-$ ternatively, true differences with respect to race or geography may exist, perhaps related to genetic or acquired differences in immune response. 
The case fatality rate of Marburg hemorrhagic fever was far greater in the area of Durba and Watsa than in European outbreaks in 1967, in which 7 of 32 patients died ( 22 percent), or cumulatively in the minor outbreaks in eastern and southern Africa, in which 3 of 6 people died (50 percent), but was similar to rates reported for a recent outbreak of Marburg hemorrhagic fever in Angola and for outbreaks of the Zaire subtype of Ebola virus infection..$^{1-3,6,9,26,30}$ Possible explanations for the high case fatality rate in the area of Durba and Watsa are limited access to sophisticated health care and the fact that many patients had to be conveyed over $15 \mathrm{~km}$ of rough road from Durba to a hospital in Watsa without motorized transport. Other possible factors included a high prevalence of underlying malnutrition, coinfections (with malaria and human immunodeficiency virus), and potential differences in infectious dose or route of inoculation. (Most infections in Europe were associated with contact with infected monkeys.) Since infection with individual genetic lineages of virus could be confirmed in only a small number of patients, a comparison of the virulence of various strains cannot be made, but the high overall death rate implies that the lineages were uniformly lethal under the circumstances of the outbreak.

With the exception of recent outbreaks of Ebola hemorrhagic fever in Gabon and Congo, in which multiple independent chains of transmission resulted from contact with infected nonhuman primates, molecular and epidemiologic data from most filovirus outbreaks suggest the occurrence of a single primary introduction or relatively few primary introductions of infection into humans, followed by propagation through humanto-human contact. ${ }^{31-37}$ In contrast, the evidence from the area of Durba and Watsa suggests that multiple, short, independent chains of humanto-human transmission occurred. This hypothesis is supported by evidence that at least nine genetic lineages of virus circulated during the outbreak, as well as the occurrence of identical lineages within but not across clusters of epidemiologically linked cases (Fig. 2). Since laboratory tests were applied to a minority of cases, there could have been additional, undiscovered lineages of virus.

It is possible that mining was a confounding variable for some other common exposure to infection. However, no other obvious commonality between miners with Marburg hemorrhagic fever could be elicited, and the association between Marburg hemorrhagic fever and the Durba village, which extended over many years, ceased abruptly with the closure of the Goroumbwa mine. The perpetuation of multiple lineages of virus over many years in a fixed location would require a suitably large reservoir of a host population, with constant recruitment of susceptible animals through reproduction or migration. Generally, only small vertebrate or invertebrate populations fulfill these criteria. There were no large, wild vertebrate populations in the vicinity of Durba, and existing evidence suggests that large mammals are more likely to be dead-end hosts (or, at most, intermediate hosts) for the filoviruses. ${ }^{31,38-40}$ Primary infection with Marburg virus was putatively linked to entry into the Kitum cave on the slopes of Mt. Elgon in Kenya in two of the four previously recorded outbreaks of Marburg hemorrhagic fever. ${ }^{6,7}$ As in the Durba outbreak, isolates in the 1980 and 1987 outbreaks in Kenya span the known genetic diversity of Marburg virus (Fig. 2), implying the existence of a long association of the virus with a reservoir host population in the cave. Thus, the cumulative evidence suggests that the reservoir of Marburg virus inhabits or frequents caves and mines or similar habitats.

Supported by the Office of Foreign Disaster Assistance of the U.S. Agency for International Development and the Department of Communicable Disease Surveillance and Response, World Health Organization, Geneva.

No potential conflict of interest relevant to this article was reported.

This article is dedicated to Dr. Innocent Katenga Bonzali and his family. Dr Bonzali died of Marburg hemorrhagic fever while investigating the outbreak described here.

We are indebted to the inhabitants, patients, families, health care workers, leaders, and authorities of Durba-Watsa for their invaluable contribution to the investigation and control of Marburg hemorrhagic fever in the area; to the administration of the OKIMO mining company in Durba for their assistance during the outbreak and subsequent investigations; and to Laura Morgan and Kent Wagoner for technical assistance in the preparation of the manuscript.

\section{APPENDIX}

The following members of the International Scientific and Technical Committee for Marburg Hemorrhagic Fever Control in the Democratic Republic of the Congo participated in the study: World Health Organization, Geneva — R. Arthur, A. Belli, G. Rodier; Institut de Médecine Tropicale du Service de Santé des Armées, Marseille, France - E. Bertherat; CDC, Atlanta — R. Downing, C.J. Peters, W.-J. Shieh; Barrick-OKIMO Mining, Durba, Democratic Republic of the Congo - F. Chimbalanga, G. Kiza, C. Nakwa, P. Nbuluyo; World Health Organization, Kampala, 
Uganda - M. Grabowsky, K. Khantaway; Ministry of Health, Kinshasa, Democratic Republic of the Congo - M.N. Kassa; World Health Organization, Kinshasa|Kisangani, Democratic Republic of the Congo - L. Kinuani; World Health Organization, Harare, Zimbabwe - K.M. Kondé, O. Tomori; Médecins sans Frontières, Belgium — J.-P. Mustin; Institut Pasteur, Cayenne, French Guiana — A. Talarmin; and Uganda Virus Research Institute, Entebbe, Uganda - B. Tugume.

REFERENCES

1. Siegert R, Shu HL, Slenczka HL, Peters D, Muller G. The aetiology of an un known human infection transmitted by monkeys (preliminary communication). Ger Med Mon 1968;13:1-2.

2. Martini GA, Knauff HG, Schmidt HA, Mayer G, Baltzer G. A hitherto unknown infectious disease contracted from monkeys: "Marburg-virus" disease. Ger Med Mon 1968;13:457-70.

3. Todorovitch K, Mocitch M, Klasnja R. Clinical picture of two patients infected by the Marburg vervet virus. In: Martin GA, Siegert R, eds. Marburg virus disease. Berlin: Springer-Verlag, 1971:19-23.

4. Feldmann H, Slenczka W, Klenk HD. Emerging and reemerging of filoviruses. Arch Virol Suppl 1996;11:77-100.

5. Gear JS, Cassel GA, Gear AJ, et al. Outbreak of Marburg virus disease in Johannesburg. Br Med J 1975;4:489-93.

6. Smith DH, Johnson BK, Isaacson $M$ et al. Marburg-virus disease in Kenya. Lancet 1982;1:816-20.

7. Johnson ED, Johnson BK, Silverstein D et al. Characterization of a new Marburg virus isolated from a 1987 fatal case in Kenya. Arch Virol Suppl 1996;11:101-14.

8. Nikiforov VV, Turovskii Iu I, Kalinin $\mathrm{PP}$, et al. A case of a laboratory infection with Marburg fever. Zh Mikrobiol Epidemiol Immunobiol 1994;3:104-6. (In Russian.)

9. Outbreak of Marburg virus hemor rhagic fever - Angola, October 1, 2004March 29, 2005. MMWR Morb Mortal Wkly Rep 2005;54:308-9.

10. Bertherat E, Talarmin A, Zeller $\mathrm{H}$ Democratic Republic of the Congo: between civil war and the Marburg virus. Med Trop (Mars) 1999;59:201-4. (In French.)

11. Biot M. Tribute to Dr. Katenga Bonzali. Trop Med Int Health 2000;5:384.

12. Marburg fever, Democratic Republic of the Congo. Wkly Epidemiol Rec 1999 74:145.

13. Viral haemorrhagic fever/Marburg Democratic Republic of the Congo. Wkly Epidemiol Rec 1999;74:157-8.

14. Colebunders R, Sleurs H, Pirard P, et al. Organisation of health care during an outbreak of Marburg haemorrhagic fever in the Democratic Republic of Congo, 1999. J Infect 2004;48:347-53.

15. Ksiazek TG, West CP, Rollin PE, Jahrling $\mathrm{PB}$, Peters CJ. ELISA for the detection of antibodies to Ebola viruses. J Infect Dis 1999;179:Suppl 1:S192-S198.

16. Ksiazek TG, Rollin PE, Williams AJ, et al. Clinical virology of Ebola hemorrhagic fever (EHF): virus, virus antigen, and IgG and IgM antibody findings among EHF patients in Kikwit, Democratic Republic of the Congo, 1995. J Infect Dis 1999;179 Suppl 1:S177-S187.

17. Sanchez A, Ksiazek TG, Rollin PE, et al. Detection and molecular characterization of Ebola viruses causing disease in human and nonhuman primates. J Infect Dis 1999;179:Suppl 1:S164-S169.

18. Geisbert TW, Jaax NK. Marburg hem orrhagic fever: report of a case studied by immunohistochemistry and electron microscopy. Ultrastruct Pathol 1998;22:3-17.

19. Borchert M, Muyembe-Tamfum JJ, Colebunders R, Libande M, Sabue M, Van Der Stuyft P. Short communication: a cluste of Marburg virus disease involving an in fant. Trop Med Int Health 2002;7:902-6.

20. Bwaka MA, Bonnet MJ, Calain P, et al. Ebola hemorrhagic fever in Kikwit, Democratic Republic of the Congo: clinical observations in 103 patients. J Infect Dis 1999;179:Suppl 1:S1-S7.

21. Stille W, Bohle E. Clinical course and prognosis of Marburg virus ("green monkey”) disease. In: Martini GA, Siegert R, eds. Marburg virus disease. Berlin: Spring er-Verlag, 1971:10-8.

22. Egbring R, Slenczka W, Baltzer G. Clinical manifestations and mechanism of the haemorrhagic diathesis in Marburg virus disease. In: Martini GA, Siegert R, eds. Marburg virus disease. Berlin: Spring er-Verlag, 1971:42-9.

23. Bausch DG, Borchert M, Grein T, et al. Risk factors for Marburg hemorrhagic fever, Democratic Republic of the Congo. Emerg Infect Dis 2003;9:1531-7.

24. Monath TP. Ecology of Marburg and Ebola viruses: speculations and directions for future research. J Infect Dis 1999;179: Suppl 1:S127-S138.

25. Borchert M, Mulangu S, Swanepoel R, et al. Serosurvey on household contacts of Marburg patients. Emerg Infect Dis 2006 12:433-9.

26. Khan AS, Tshioko FK, Heymann DL, et al. The reemergence of Ebola hemorrhagic fever, Democratic Republic of the Congo, 1995. J Infect Dis 1999;179:Supp 1:S76-S86.

27. Outbreak of Ebola hemorrhagic fever, Uganda, August 2000-January 2001 MMWRMorb Mortal Wkly Rep 2001;50:73-

28. Ebola haemorrhagic fever in Sudan, 1976: report of a WHO/International Study Team. Bull World Health Organ 1978;56: $247-70$
29. Pattyn S, van der Groen G, Courteille G, Jacob W, Piot P. Isolation of Marburglike virus from a case of haemorrhagic fever in Zaire. Lancet 1977;1:573-4.

30. Ebola haemorrhagic fever in Zaire 1976. Bull World Health Organ 1978;56: 271-93.

31. Leroy EM, Rouquet P, Formenty P, et al. Multiple Ebola virus transmission events and rapid decline of central African wildlife. Science 2004;303:387-90. [Erratum, Science 2004;303:628.]

32. Bausch DG, Rollin PE. Responding to epidemics of Ebola hemorrhagic fever: progress and lessons learned from recent outbreaks in Uganda, Gabon, and Congo. In: Scheld WM, Murray BE, Hughes JM, eds. Emerging infections 6. Washington, D.C.: ASM Press, 2004:35-57.

33. Rodriguez LL, De Roo A, Guimard Y, et al. Persistence and genetic stability of Ebola virus during the outbreak in Kikwit, Democratic Republic of the Congo, 1995. J Infect Dis 1999;179:Suppl 1:S170-S176.

34. Georges AJ, Leroy EM, Renaut AA, et al. Ebola hemorrhagic fever outbreaks in Gabon, 1994-1997: epidemiologic and health control issues. J Infect Dis 1999; 179:Suppl 1:S65-S75.

35. Leroy EM, Baize S, Mavoungou E, Apetrei C. Sequence analysis of the GP, NP, VP40 and VP24 genes of Ebola virus isolated from deceased, surviving and asymptomatically infected individuals during the 1996 outbreak in Gabon: comparative studies and phylogenetic characterization. J Gen Virol 2002;83:67-73.

36. Leroy EM, Souquiere S, Rouquet P, Drevet D. Re-emergence of Ebola haemorrhagic fever in Gabon. Lancet 2002;359: 712.

37. Towner JS, Rollin PE, Bausch DG, et al. Rapid diagnosis of Ebola hemorrhagic fever by reverse transcription-PCR in an outbreak setting and assessment of patient viral load as a predictor of outcome. J Virol 2004;78:4330-41.

38. Formenty P, Boesch C, Wyers M, et al. Ebola virus outbreak among wild chimpanzees living in a rain forest of Cote d'Ivoire. J Infect Dis 1999;179:Suppl 1: S120-S126.

39. Walsh PD, Abernethy KA, Bermejo M, et al. Catastrophic ape decline in western equatorial Africa. Nature 2003;422:611-4. 40. Peterson AT, Bauer JT, Mills JN. Ecologic and geographic distribution of filovirus disease. Emerg Infect Dis 2004;10 40-7.

Copyright (c) 2006 Massachusetts Medical Society. 